\title{
Cette soie marine a d'autres reflets
}

Supplément à la note d'Aurore Sagot-Ortéga sur les tissages de byssus

\section{Claude Lefébure}

\section{(2) OpenEdition}

Journals

Édition électronique

URL : https://journals.openedition.org/tc/676

DOI : $10.4000 /$ tc. 676

ISSN : 1952-420X

Éditeur

Éditions de l'EHESS

\section{Édition imprimée}

Date de publication : 1 mai 1993

ISSN : 0248-6016

\section{Référence électronique}

Claude Lefébure, "Cette soie marine a d'autres reflets », Techniques \& Culture [En ligne], 19| 1993, mis en ligne le 10 janvier 2006, consulté le 29 septembre 2022. URL : http://journals.openedition.org/tc/ 676 ; DOI : https://doi.org/10.4000/tc.676

Ce document a été généré automatiquement le 29 septembre 2022.

Tous droits réservés 


\section{Cette soie marine a d'autres reflets}

Supplément à la note d'Aurore Sagot-Ortéga sur les tissages de byssus

Claude Lefébure 